\title{
A comparative study of pollination methods effect on the changes in fruit yield and quality of date palm cultivar Khalas
}

\author{
Muhammad Munir1,2*, Mohammed Refdan Al-Hajhoj1, Hesham Sayed Ghazzawy1,3, Abdel-Kader Mohammed Sallam1,4, \\ Abdul Majeed Al-Bahigan1, Mubarak Ali Al-Muiweed1 \\ ${ }^{1}$ Date Palm Research Center of Excellence, King Faisal University, Al-Ahsa, Saudi Arabia \\ ${ }^{2}$ Frontier Agriculture, SOYL Precision Crop Production Division, Newbury, United Kingdom \\ ${ }^{3}$ Central Laboratory for Date Palm Research and Development, Agriculture Research Center, Giza, Egypt \\ ${ }^{4}$ College of Technology and Development, Zagazig University, Egypt
}

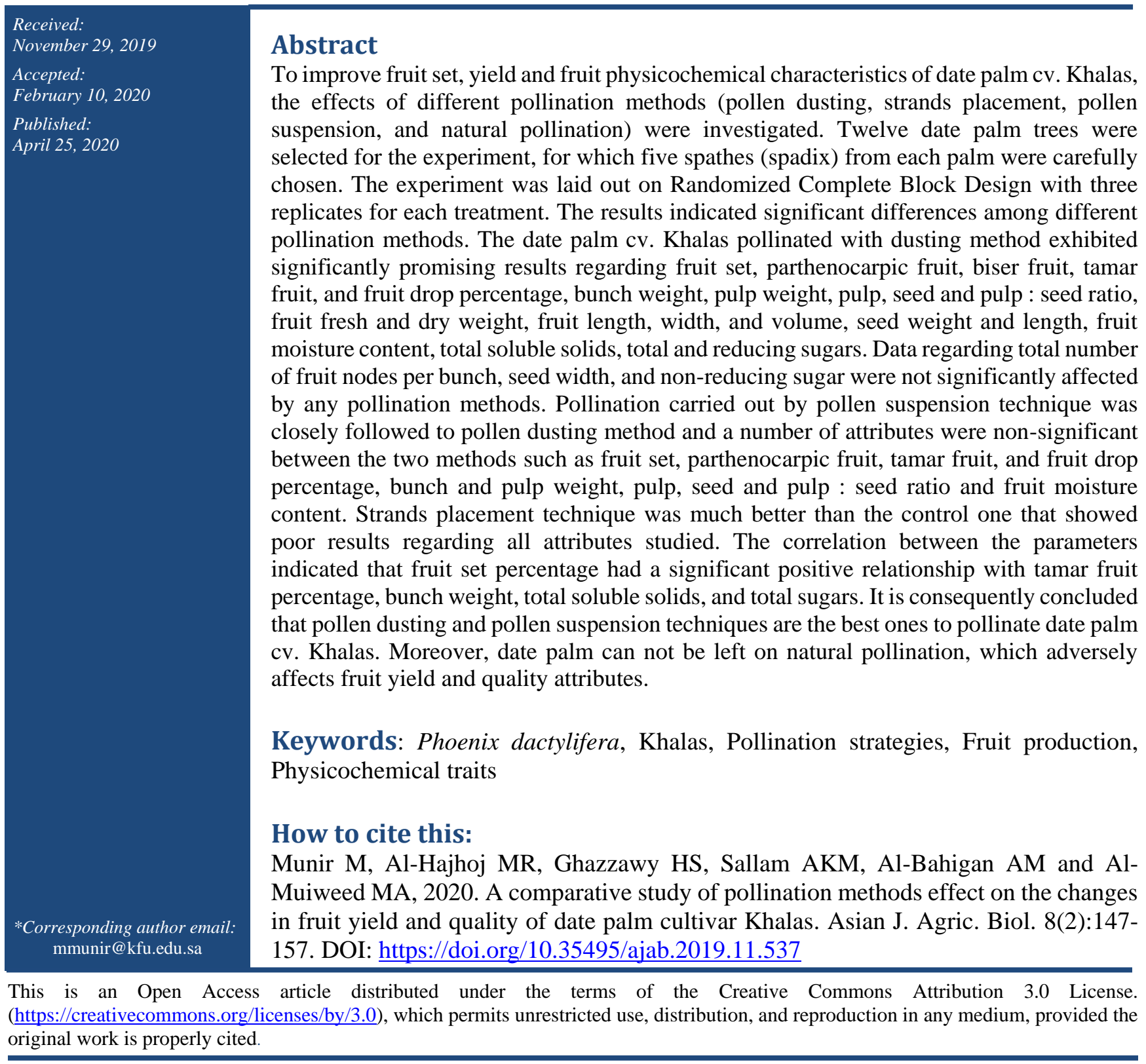




\section{Introduction}

Date palm (Phoenix dactylifera L.) is grown in arid and semi-arid regions on 1.34 million hectares and produced 8.17 million tons of fruit across the globe (FAOSTAT, 2017). There are more than 120 million date palm trees worldwide yielding several million tons of dates annually, besides its secondary products. The Arab world has more than 84 million date palm trees with the majority in Egypt, Iraq, Saudi Arabia, Algeria, Morocco, Tunisia, United Arab Emirates and Iran (Abd-Rabou and Radwan, 2017). There are 70\% of the world's date palm trees in the Arab countries and are contributed $67 \%$ of the global production. Kingdom of Saudi Arabia has more than 23 million date palm trees, which produce about one million tons of dates annually (Al-Abdoulhadi et al., 2011). Date palm cv. Khalas is a mid-season cultivar and is widely cultivated in the Al-Hassa oasis on more than $60 \%$ of the date palm growing area. It is considered as the best date in the region, having good sized fruit that is consumed at fresh (rutab) and semi-dry (tamar) stages and has a long shelf life.

Date palm is a cross-pollinated fruit tree, due to its dioecious nature, where pollen grains from male palm are applied on to fruit buds bearing female palm (Bekheet and Hanafy, 2011). Pollen tube formation initiates, which is precisely guided by female cues (Higashiyama and Takeuchi, 2015). Several femalesecreted peptides are identified that specifically control the direction of pollen tube growth (Takeuchi and Higashiyama, 2012). The molecular mechanism of pollination and fertilization indicated the importance of fruit setting and yield attributes, particularly for a dioecious species like date palm.

The date palm is naturally wind or insect-pollinated but this method has proven inefficient and economically unfeasible (El-Mardi et al., 1998). Failure of effective pollination leads to the formation of triple parthenocarpic fruits of no economic value (Zaid and de Wet, 2002). To tackle this problem, artificial pollination is considered to be important to improve crop productivity and quality, which is commonly practiced in commercial date palm plantations (Gupta et al., 2017). Pollination of 60-80\% of the female flowers is considered satisfactory and will usually lead to a good fruit set and yield (Ream and Furr, 1969). The pollination efficiency is affected by several factors and consequently fruit set is highly dependent on these factors such as pollen sources, pollination time, pollination methods, male flowering time, pollens viability, amount and quality, and the female flowers receptivity (Zaid and de Wet, 2002; Ahmed et al., 2016; Abdel-Sattar and Mohamed, 2017). Therefore, numbers of date palm pollination methods have been adopted to attain maximum fruit set and yield benefits such as male strands (spikes) placement, pollen dusting, pollen suspension methods, etc. (Haffar et al., 1997; Hajian, 2005; ElDengawy, 2017; Munir, 2019). The date palm growers according to their experience and pollen source availability approve these pollination methods. However, adopting an appropriate and improved pollination method could save pollen grains and enhance fruit yield (Awad, 2010). Moreover, due to the substantial increase in date palm numbers across the world, the growers and researchers are prompted to adopt alternative unconventional methods of pollination, which minimize the labor-cost and improve crop production.

Several studies have been conducted to find out the optimal method of pollination for date palm, which varied with the pollen source and concentrations, cultivars response and ecological locations. Attalla et al. (1998) reported that different concentrations of pollen grains when applied through dusting technique significantly increased the fruit set percentage. AlWusaibai et al. (2012) compared manual pollination technique with mechanical dusting one in date palm cvs. Khalas and Sheshi and reported highest fruit set and lowest fruit drop when pollens were applied using manual technique. However, yield per bunch was significantly higher when mechanical dusting pollination technique was used. El-Mardi et al. (2007) evaluated the significance of hand dusting pollination and mechanical dusting methods in date palm cvs. Khalas and Khasab and they observed a nonsignificant effect between both methods regarding fruits number, weight per strand and fruit diameter, however, cv. Khalas yield was higher in mechanical dusting pollination, but with lower fruit length and weight than the hand dusting pollination. This effect was not significant in cv. Khasab. Khan and Khan (1993) and Iqbal et al. (2010) reported that pollen dusting and strand placement methods are best as compared to natural pollination in date palm $\mathrm{cv}$. Dhakki regarding fruit set percentage, number of fruits per bunch and physical properties of fruit. Similarly, Shaaban et al. (2019) concluded that pollination by either pollen grains suspension or dusting enhanced the yield and quality of date palm cv. Saidy. Munir (2019) reported that 3-4 g pollen 
suspension significantly enhanced yield and quality of cvs. Khadrawy and Zahidi.

The traditional date palm growers in Saudi Arabia mostly practice conventional strands placement method of pollination or they leave the tree to allow natural pollination and are unaware of the other improved techniques. The placement of number of strand per spathe is also irregular that varies from 310 strands per spathe. This imbalance strands placement often resulted in lowest fruit set and yield. Keeping in view the importance of date palm pollination methods, a study was designed to compare the effects of different pollination techniques on fruit set, yield and physicochemical attributes of date palm $\mathrm{cv}$. Khalas under the arid agro-climatic condition of Al-Ahsa, Saudi Arabia.

\section{Material and Methods}

The present study was conducted at the orchard of Research and Training Station, King Faisal University, Al-Ahsa, Kingdom of Saudi Arabia during 2017 and 2018 (Latitude 25 $5^{\circ} 16^{\prime} 7.068^{\prime \prime} \mathrm{N}$ and Longitude $49^{\circ} 42^{\prime}$ 27.522" E). Twelve-year-old, cracked male spathes (inflorescences) of same source were collected from the experimental orchard to obtain pollen grains and strands (spikelet) for pollination purposes. The protective sheath of male spathes was removed with the help of a sharp knife and they were placed on Kraft brown paper sheet at ambient room temperature $\left(20-22{ }^{\circ} \mathrm{C}\right)$. Pollen grains were collected after 24 hours, were dried in glass desiccator and were kept in a refrigerator at $4{ }^{\circ} \mathrm{C}$ until pollination process. The experiment was consisted of four pollination methods:

\section{Conventional methods}

1. Natural pollination or Control (female spathes were left open to allow wind or insect pollination, as there was one male pollinizer in the orchard)

2. Strands placement method (four male strands were inserted on top of the female spathe)

\section{Non-conventional methods}

1. Pollen dusting method (pollen grains were mixed with plain flour (1:9) and were rubbed onto female spathe with soft foam duster)

2. Pollen suspension method (three grams pollen grains were diluted in one litre water and were sprayed on open female spathes using a handheld sprayer).

Twelve date palm trees were chosen for the experiment, in which five spathes (uniform strands number and size) on each palm were selected per replication and the rest were removed. The experiment was laid out on Randomized Complete Block Design (RCBD) with three replicates in each treatment. Pollination was carried out at 11 am (Iqbal et al. 2010) at the time of spathe opening of twelve-year-old, uniform female date palm cv. Khalas. All female pollinated spathes were covered with the Kraft brown wax paper bags to avoid any contamination, which were removed after fruit setting (two weeks after pollination). Date palm spathes in control were not covered in order to allow cross-pollination by wind and insects. However, around mid-summer, each fruit bunch was covered with knitted polyethylene mesh bags $(90 \times 80 \mathrm{~cm})$ for the protection from birds and insects. The agro-climatic data was downloaded from the on-farm wireless weather station, Model WS3083 (Aercus Instruments, West Yorkshire, UK), installed around 25 meters away from the experimental orchard, which recorded the respective data after every 5 minutes (Table 1).

Table-1: Climatic information of the research site during experimental year 2017-18.

\begin{tabular}{|c|c|c|c|c|c|c|c|c|c|c|c|c|}
\hline \multirow{3}{*}{$\begin{array}{l}\text { Growing } \\
\text { Season }\end{array}$} & \multicolumn{6}{|c|}{ 2017-18 Temperature $\left({ }^{\circ} \mathrm{C}\right)$} & \multirow{2}{*}{\multicolumn{2}{|c|}{$\begin{array}{l}\text { Relative humidity } \\
(\%)\end{array}$}} & \multirow{2}{*}{\multicolumn{2}{|c|}{$\begin{array}{c}\text { Wind speed } \\
(\mathrm{km} / \mathrm{h})\end{array}$}} & \multirow{2}{*}{\multicolumn{2}{|c|}{$\begin{array}{l}\text { Precipitation } \\
(\mathrm{mm})\end{array}$}} \\
\hline & \multicolumn{2}{|c|}{ Maximum } & \multicolumn{2}{|c|}{ Minimum } & \multicolumn{2}{|c|}{ Average } & & & & & & \\
\hline & 2017 & 2018 & 2017 & 2018 & 2017 & 2018 & 2017 & 2018 & 2017 & 2018 & 2017 & 2018 \\
\hline March & 22 & 34 & 16 & 17 & 22 & 25 & 44 & 29 & 14.66 & 13.68 & 9.56 & 0.00 \\
\hline April & 38 & 35 & 21 & 21 & 29 & 28 & 25 & 32 & 16.78 & 18.43 & 0.00 & 2.15 \\
\hline May & 43 & 40 & 26 & 24 & 35 & 32 & 18 & 22 & 17.66 & 14.66 & 2.50 & 0.84 \\
\hline June & 45 & 45 & 28 & 30 & 36 & 38 & 13 & 13 & 18.88 & 19.88 & 0.00 & 0.00 \\
\hline July & 48 & 46 & 30 & 31 & 39 & 39 & 18 & 14 & 12.77 & 21.03 & 0.00 & 0.00 \\
\hline August & 46 & 46 & 30 & 29 & 38 & 38 & 28 & 17 & 10.50 & 17.92 & 0.00 & 0.00 \\
\hline September & 44 & 44 & 26 & 27 & 35 & 35 & 33 & 33 & 13.08 & 10.63 & 0.00 & 0.00 \\
\hline
\end{tabular}

Maximum and minimum temperatures, relative humidity, wind speed and precipitation in each cell represent the average values of year 2017 and 2018. 
The weather data was also cross-checked with the local weather station. All the standard cultural practices were carried out uniformly. The data were recorded on the following variables: fruit set, parthenocarpic fruit (unfertilized or shees), biser fruit (unripe), tamar fruit (ripe), and fruit drop percentage, total number of fruit nodes per bunch, bunch weight and pulp weight, pulp, seed and pulp : seed ratio, fruit fresh and dry weight, fruit length, width and volume, seed weight, length and width, fruit moisture content, total soluble solids, total, reducing and non-reducing sugars according to standard methods (AOAC, 2016). The collected data were statistically analysed using Statistical Analysis Software, Release 9.4 (SAS Institute, North Carolina, USA) and the Duncan Multiple Range Test was applied to determine the least significance difference between the means.

\section{Results and Discussion}

Table 2 indicated a statistically significant $(\mathrm{p} \leq 0.05)$ effect of different pollination methods on the fruit set, parthenocarpic fruit, biser fruit, tamar fruit, and fruit drop percentage, and bunch weight of date palm $\mathrm{cv}$. Khalas. However, there was a non-significant effect of different pollination methods on the total No. of fruit nodes per bunch. Maximum fruit set $(85.71 \%)$ was recorded in pollen suspension method followed by pollen dusting method $(82.07 \%)$, as both were statistically at par however, minimum fruit set (26.03\%) was observed when female flowers were left to open pollination (control). Similar results were reported by Mostaan et al. (2010) in date palm cv. Barhee, which was pollinated by mechanical dusting technique and compared with traditional strands placement one. There was significantly higher percentage to fruit set in former technique. Shaaban et al. (2019) reported that date palm cv. Saidy set highest fruit percentage $(86.21 \%)$ when pollinated by hand followed by dusting $(72.11 \%)$ and pollen grains suspension (62.76\%) methods. Iqbal et al. (2010) obtained highest fruit set percentage in cv. Dhakki from placement method followed by dusting and pollen grains suspension techniques as compared to natural pollination, which showed lowest fruit set. Khan and Khan (1993) reported similar results in cv. Dhakki by adopting strands placement method and dusting technique. Attalla et al. (1998) observed lowest fruit set in natural pollination method in cvs.
Sukari and Hellawa. The higher percentage of fruit set by dusting and pollen suspension methods could be due to the reason that the pollen grains did not need to release from male strands in case of strands placement method or need a mode of pollen dispersion (wind), which minimize the fruit set time when the female flower bud is mature to receive pollen.

Data regarding parthenocarpic fruit percentage indicated that the female bunches in control had maximum percentage of parthenocarpic fruits $(7.81 \%)$ whereas bunches sprayed pollen through suspension method produced significantly lower number of parthenocarpic fruits $(0.32 \%)$ closely followed by pollen dusting method $(0.64 \%)$. There are many reasons for parthenocarpic fruit development such as male or female incompatibility (Zaid and de Wet, 2002), environmental factors (Pandolfini et al., 2018), hormonal deregulation (Jacobsen and Olszewski, 1993), delay or rapid growth of ovary due to the changes in regulation of gibberellin (Smith and Koltunow, 1999) and low $\left(8-20{ }^{\circ} \mathrm{C}\right)$ temperatures (Cohen et al., 2016). In present study, fruit bunches left for natural pollination produced maximum percentage of parthenocarpic fruits that could be due to the minimal number of pollens visited stigma or failure of pollen grains to fertilize female ovary. Khan and Khan (1993) reported highest number of imperfect fruit per bunch (232) when plants were subjected to natural pollination in cv. Dhakki as compared to dusting (85) and strands placement (12) pollination techniques.

More or less similar trend was observed regarding biser fruit percentage, as highest percentage (6.23\%) was noted in control, which was statistically at par with strands placement method (6.13\%). However, minimum biser percentage $(0.64 \%)$ was in spathes, which were pollinated by dusting method. Similarly, maximum tamar fruit percentage was observed when the female spathes were pollinated by pollen suspension methods $(82.43 \%)$, which was statistically non-significant to pollen dusting method (81.43\%). However, it was minimum (19.81\%) when cv. Khalas was set aside to allow open pollination. Although the present study reported a significant effect of pollination techniques on biser fruits, which is otherwise influenced by biochemical changes, low respiration rate, low external temperature and inappropriate relative humidity during fruit development phases. 
Muhammad Munir et al.

Table-2: Effects of different pollination methods on the yield and yield components of date palm cv. Khalas.

\begin{tabular}{|l|c|c|c|c|c|}
\hline \multirow{2}{*}{\multicolumn{1}{|c|}{ Parameters }} & \multicolumn{4}{c|}{ Pollination Methods } & \multirow{2}{*}{ LSD $(5 \%)$} \\
\cline { 2 - 6 } & Control & Strands Placement & Pollen Dusting & Pollen Suspension & \\
\hline Fruit set (\%) & $26.03^{\mathrm{c}}( \pm 1.84)$ & $68.67^{\mathrm{b}}( \pm 1.92)$ & $82.07^{\mathrm{a}}( \pm 3.66)$ & $85.71^{\mathrm{a}}( \pm 1.02)$ & $7.66^{*}$ \\
\hline Parthenocarpic fruits (\%) & $7.81^{\mathrm{a}}( \pm 0.53)$ & $3.66^{\mathrm{b}}( \pm 1.18)$ & $0.64^{\mathrm{c}}( \pm 0.17)$ & $0.32^{\mathrm{c}}( \pm 0.10)$ & $1.79^{*}$ \\
\hline Biser fruits $(\%)$ & $6.23^{\mathrm{a}}( \pm 0.27)$ & $6.13^{\mathrm{a}}( \pm 0.40)$ & $0.64^{\mathrm{c}}( \pm 0.30)$ & $2.98^{\mathrm{b}}( \pm 0.94)$ & $1.82^{*}$ \\
\hline Tamar fruits (\%) & $19.81^{\mathrm{c}}( \pm 1.76)$ & $62.55^{\mathrm{b}}( \pm 2.16)$ & $81.43^{\mathrm{a}}( \pm 3.82)$ & $82.73^{\mathrm{a}}( \pm 1.79)$ & $8.58^{*}$ \\
\hline Fruit drop (\%) & $66.16^{\mathrm{a}}( \pm 2.08)$ & $27.67^{\mathrm{b}}( \pm 2.18)$ & $17.29^{\mathrm{c}}( \pm 3.50)$ & $13.97^{\mathrm{c}}( \pm 1.03)$ & $8.23^{*}$ \\
\hline Fruit nodes/bunch & $781.60^{\mathrm{a}}( \pm 14.99)$ & $789.60^{\mathrm{a}}( \pm 28.42)$ & $694.80^{\mathrm{a}} \pm(72.57)$ & $747.00^{\mathrm{a}}( \pm 27.68)$ & $110.59^{\mathrm{NS}}$ \\
\hline Bunch weight $(\mathrm{kg})$ & $1.22^{\mathrm{c}}( \pm 0.09)$ & $4.01^{\mathrm{b}}( \pm 0.23)$ & $6.45^{\mathrm{a}}( \pm 0.93)$ & $6.14^{\mathrm{a}}( \pm 0.32)$ & $1.49^{*}$ \\
\hline
\end{tabular}

Similar letter(s) in a row are non-significant statistically at $\mathrm{P} \leq 0.05$. Figures in parentheses represent the standard errors. * represents the significant statistical difference between the means of each treatment whereas NS indicates the non-significant statistical difference.

Date fruit is categorized as climacteric fruit and the ripening processes are associated with a concurrent increase in the internal ethylene concentration and higher rate of respiration (Abbas and Ibrahim, 1996 \& 1998) and are used as benchmarks in establishing the ripening. However, a few reports described the absence or reduced peak in respiration when fruits are ripened on the tree, despite a distinct rise in ethylene concentration (Saltveit, 1993; Bower et al., 2002).

Minimum fruit drop percentage was recorded when female bunches were sprayed with pollen suspension method (13.97\%) that was at par with pollen dusting method (17.29\%) whereas maximum fruit drop was counted in control $(66.16 \%)$. It is suggested that the large fruit size and shorter internodes space could be the factors playing role in the higher percentage of fruit drop in date palm cultivars (Shafique et al., 2011). However, Iqbal et al., (2005) observed highest fruit drop in natural pollination whereas it was minimum in strands placement method followed by liquid spray and dusting methods. Al-Wusaibai et al. (2012) found non-significant difference in fruit drop between manual and mechanical pollen application methods in cvs. Khalas and Sheshi. Data regarding number of fruit nodes per bunch was non-significant statistically, however highest fruit nodes number were counted in control (781.60) followed by strands placement (789.60), pollen suspension (747) and pollen dusting (694.80) methods. El-Mardi et al. (2007) reported similar non-significant effect of hand and mechanical pollination methods in cvs. Khalas and Khasab. However, Khan and Khan (1993) reported highest number of fruit per bunch (500) by adopting strands placement method for cv. Dhakki followed by dusting technique (401) as compared to natural pollination (229).

The trend observed for bunch weight showed that it was maximum $(6.45 \mathrm{~kg})$ when pollens were dusted onto the female spathe, which was statistically alike with pollen suspension method $(6.14 \mathrm{~kg})$. Female palms subjected to the open pollination condition produced significantly lower bunch weight $(1.22 \mathrm{~kg})$. Similar results were reported in cv. Hillawi (Ullah et al., 2018) and cv. Khalas (Haffar et al., 1997) when pollen dusting method was applied. Iqbal et al. (2005, 2010) obtained significantly lower bunch weight in natural pollination method however there was statistically non-significant difference among artificial pollination methods viz. dusting, placement and liquid spray in cv. Dhakki. However, Samouni et al. (2016) and Shaaban et al. (2019) reported non-significant difference among different pollination methods regarding bunch weight. The reasons of difference between these two studies and present one regarding bunch weight could be because of the difference in cultivars and both former studies applied different percentage of pollen grain concentrations and starch levels that might negatively affect bunch weight.

Data in Table 3 showed that the effect of different pollination methods was statistically significant $(\mathrm{P} \leq 0.05)$ regarding fruit fresh and dry weight, fruit length, width, and volume, seed weight and length, pulp weight, pulp, seed and pulp : seed ratio, fruit moisture content, total soluble solids, total and reducing sugars of date palm cv. Khalas. However, there was non-significant effect of pollination methods on seed width and non-reducing sugar. Maximum fruit fresh weight $(11.20 \mathrm{~g})$, fruit dry 
weight $(8.93 \mathrm{~g})$, fruit length $(37.06 \mathrm{~mm})$, fruit width $(23.14 \mathrm{~mm})$ and fruit volume $(10.69 \mathrm{ml})$ were measured when the bunches were pollinated by dusting method, which was followed by pollen suspension method (fruit fresh weight $9.94 \mathrm{~g}$, fruit dry weight $7.95 \mathrm{~g}$, fruit length $34.68 \mathrm{~mm}$, fruit width 20.81 $\mathrm{mm}$ and fruit volume $10.03 \mathrm{ml}$ ). On the other hand, these parameters (fruit fresh weight $(7.91 \mathrm{~g}$ ), fruit dry weight $(6.46 \mathrm{~g})$, fruit length $(31.83 \mathrm{~mm})$, fruit width $(18.58 \mathrm{~mm})$ and fruit volume $(8.75 \mathrm{ml})$ were minimum in control. More or less similar trend was observed in strands placement method. Data regarding seed weight was higher in control $(1.19 \mathrm{~g})$ followed by strands placement method (1.15 g) as both were statistically non-significant. However, minimum seed weight $(1.00 \mathrm{~g})$ was obtained in pollen dusting and pollen suspension methods. Seed length was slightly higher in strands placement method $(20.49 \mathrm{~mm})$ followed by control $(20.47 \mathrm{~mm})$ and pollen suspension method $(20.38 \mathrm{~mm})$, however, it was lowered in pollen dusting method $(19.38 \mathrm{~mm})$. Although the seed width was non-significant statistically, however, it was maximum in strands placement method $(8.61 \mathrm{~mm})$ followed by control $(8.41 \mathrm{~mm})$, pollen suspension method $(8.11 \mathrm{~mm})$ and pollen dusting method $(7.91 \mathrm{~mm})$. Highest fruit weight and size was recorded in cv. Saidy when dusting and pollen suspension methods were applied (Shaaban et al., 2019) whereas highest seed weight, fruit length, width and weight was obtained in pollen dusting method (Ullah et al., 2018). Abu-Zahra and Shatnawi (2019) obtained higher fruit weight in cvs. Medjol and Barhee when treated with water suspension technique compared to hand application method. Iqbal et al. $(2005,2010)$ reported that seed weight was higher when cv. Dhakki pollinated with liquid spray methods, however, there was a nonsignificant difference between hand, dusting, placement and liquid pollination methods regarding fruit weight and fruit length parameters. Al-Wusaibai et al. (2012) reported a significant difference in fruit length and width in cv. Sheshi when pollinated by mechanical dusting compared to manual pollination method. The same trend was in cv. Khalas however, fruit width was non-significant. Haffar et al. (1997) observed significantly higher results in cv. Khalas related to seed weight, fruit weight, length and diameter when female bunches pollinated by hand. The difference between these studies and the present one could be due to the effects of xenia and metaxenia of pollen source.
Data regarding pulp weight showed that it was maximum $(10.20 \mathrm{~g})$ when pollen dusting method was practiced followed by pollen suspension method (8.94 $\mathrm{g}$ ), however, the same parameter was recorded minimum $(6.71 \mathrm{~g})$ in control, which was closely followed by strands placement method $(6.95 \mathrm{~g})$. Similar trend was observed regarding pulp ratio attribute that was highest ratio (91.01 and 89.90$)$ by pollen dusting and pollen suspension methods, respectively compared to control (84.88). Data regarding seed ratio was opposite to the pulp ratio wherein maximum seed ratio (15.12) was recorded when open pollination was allowed followed by strands placement (14.28) method, which were statistically at par. The same parameter was minimum (8.99) when dusting pollination method was applied followed by pollen suspension method (10.10). Similarly, pulp : seed ratio trend was like pulp ratio trend, which was maximum (10.50) when pollens dusting method was adopted followed by pollen suspension method (9.07) as both behaved alike. However, it was minimum in control (5.64) followed by strands placement method (6.04) and both were statistically at par. The least seed ratio signified the reason for higher pulp weight, pulp ratio and pulp : seed ratio, which were influenced by different pollination methods. Samouni et al. (2016) obtained higher pulp percentage when cv. Saidy pollinated by dusting method as compared to hand pollination. However, Iqbal et al. $(2005,2010)$ reported a nonsignificant effect of different pollination methods on pulp weight of cv. Dhakki that could be due to the difference in cultivars and the pollinizer source.

Chemical analysis of tamar fruits of date palm cv. Khalas revealed that apart from non-reducing sugar all other parameters (fruit moisture content, total soluble solids, total and reducing sugars) were significant statistically. Maximum fruit moisture content (18.44\%) was determined when bunches were left to allow open pollination followed by strands placement method $(18.04 \%)$ whereas it was minimum in pollen suspension (15.64\%) and pollen dusting (15.71\%) methods. However, total soluble solids (71.62 brix), total sugar $(58.50 \%)$ and reducing sugar $(56.09 \%)$ were higher when spathes were subjected to pollen dusting method. The same parameters were closely followed by pollen suspension and strands placement methods. However, non-reducing sugar was slight higher $(2.69 \%)$ in pollen suspension method as compared to others, although they were statistically alike. 
Table-3: Effects of different pollination methods on the fruit physicochemical characteristics of date palm cv. Khalas.

\begin{tabular}{|c|c|c|c|c|c|}
\hline \multirow{2}{*}{ Parameters } & \multicolumn{4}{|c|}{ Pollination Methods } & \multirow{2}{*}{$\operatorname{LSD}_{(5 \%)}$} \\
\hline & Control & Strands Placement & Pollen Dusting & Pollen Suspension & \\
\hline \multicolumn{6}{|c|}{$\begin{array}{l}\text { Physiological Properties of Fruit } \\
\end{array}$} \\
\hline Fruit fresh weight $(\mathrm{g})$ & $7.91^{\mathrm{c}}( \pm 0.16)$ & $8.11^{\mathrm{c}}( \pm 0.16)$ & $11.20^{\mathrm{a}}( \pm 0.37)$ & $9.94^{\mathrm{b}}( \pm 0.21)$ & $0.80^{*}$ \\
\hline Fruit dry weight $(\mathrm{g})$ & $6.46^{\mathrm{c}}( \pm 0.32)$ & $6.62^{\mathrm{c}}( \pm 0.32)$ & $8.93^{\mathrm{a}}( \pm 0.27)$ & $7.95^{\mathrm{b}}( \pm 0.20)$ & $0.75^{*}$ \\
\hline Fruit length (mm) & $31.83^{\mathrm{c}}( \pm 0.78)$ & $33.63^{\mathrm{ab}}( \pm 1.30)$ & $37.06^{\mathrm{a}}( \pm 0.91)$ & $34.68^{\mathrm{bc}}( \pm 0.56)$ & $2.46^{*}$ \\
\hline Fruit width $(\mathrm{mm})$ & $18.58^{\mathrm{c}}( \pm 0.72)$ & $18.98^{\mathrm{bc}}( \pm 0.52)$ & $23.14^{\mathrm{a}}( \pm 0.50)$ & $20.81^{\mathrm{b}}( \pm 0.81)$ & $2.02^{*}$ \\
\hline Fruit volume $(\mathrm{ml})$ & $8.75^{\mathrm{c}}( \pm 0.32)$ & $9.35^{\mathrm{bc}}( \pm 0.38)$ & $10.69^{\mathrm{a}}( \pm 0.25)$ & $10.03^{\mathrm{ab}}( \pm 0.20)$ & $0.83^{*}$ \\
\hline Seed weight $(\mathrm{g})$ & $1.19^{\mathrm{a}}( \pm 0.02)$ & $1.15^{\mathrm{a}}( \pm 0.01)$ & $1.00^{\mathrm{b}}( \pm 0.08)$ & $1.00^{\mathrm{b}}( \pm 0.05)$ & $0.13^{*}$ \\
\hline Seed length $(\mathrm{mm})$ & $20.47^{\mathrm{a}}( \pm 0.12)$ & $20.49^{\mathrm{a}}( \pm 0.11)$ & $19.38^{\mathrm{b}}( \pm 0.41)$ & $20.38^{\mathrm{a}}( \pm 0.23)$ & $0.81^{*}$ \\
\hline Seed width $(\mathrm{mm})$ & $8.41^{\mathrm{a}}( \pm 0.07)$ & $8.61^{\mathrm{a}}( \pm 0.28)$ & $7.91^{\mathrm{a}}( \pm 0.54)$ & $8.11^{\mathrm{a}}( \pm 0.47)$ & $0.96^{\mathrm{NS}}$ \\
\hline Pulp weight (g) & $6.71^{\mathrm{c}}( \pm 0.16)$ & $6.95^{\mathrm{c}}( \pm 0.19)$ & $10.20^{\mathrm{a}}( \pm 0.38)$ & $8.94^{\mathrm{b}}( \pm 0.23)$ & $0.79^{*}$ \\
\hline Pulp ratio & $84.88^{\mathrm{b}}( \pm 0.51)$ & $85.72^{\mathrm{b}}( \pm 0.49)$ & $91.01^{\mathrm{a}}( \pm 0.75)$ & $89.90^{\mathrm{a}}( \pm 0.62)$ & $1.39^{*}$ \\
\hline Seed ratio & $15.12^{\mathrm{a}}( \pm 0.51)$ & $14.28^{\mathrm{a}}( \pm 0.49)$ & $8.99^{\mathrm{b}}( \pm 0.75)$ & $10.10^{\mathrm{b}}( \pm 0.62)$ & $1.39^{*}$ \\
\hline Pulp : Seed ratio & $5.64^{\mathrm{b}}( \pm 0.22)$ & $6.04^{\mathrm{b}}( \pm 0.26)$ & $10.50^{\mathrm{a}}( \pm 1.15)$ & $9.07^{\mathrm{a}}( \pm 0.69)$ & $1.73^{*}$ \\
\hline \multicolumn{6}{|c|}{$\begin{array}{c}\text { Biochemical Properties of Fruit } \\
\end{array}$} \\
\hline Fruit moisture content $(\%)$ & $18.44^{\mathrm{a}}( \pm 0.22)$ & $18.04^{\mathrm{a}}( \pm 0.57)$ & $15.71^{\mathrm{b}}( \pm 0.56)$ & $15.64^{\mathrm{b}}( \pm 0.85)$ & $1.83^{*}$ \\
\hline Total soluble solids (brix) & $63.51^{\mathrm{c}}( \pm 0.92)$ & $67.51^{\mathrm{b}}( \pm 1.50)$ & $71.62^{\mathrm{a}}( \pm 0.69)$ & $69.60^{\mathrm{ab}}( \pm 1.59)$ & $3.15^{*}$ \\
\hline Total sugar $(\%)$ & $55.51^{\mathrm{b}}( \pm 0.62)$ & $57.71^{\mathrm{ab}}( \pm 0.60)$ & $58.50^{\mathrm{a}}( \pm 1.36)$ & $57.90^{\mathrm{ab}}( \pm 1.07)$ & $2.72^{*}$ \\
\hline Reducing sugar $(\%)$ & $53.48^{\mathrm{b}}( \pm 0.63)$ & $55.68^{\mathrm{ab}}( \pm 0.62)$ & $56.09^{\mathrm{a}}( \pm 1.23)$ & $55.22^{\mathrm{ab}}( \pm 1.02)$ & $2.25^{*}$ \\
\hline Non-reducing sugar (\%) & $2.03^{\mathrm{a}}( \pm 0.27)$ & $2.03^{\mathrm{a}}( \pm 0.27)$ & $2.42^{\mathrm{a}}( \pm 0.29)$ & $2.69^{\mathrm{a}}( \pm 0.19)$ & $0.87^{\mathrm{NS}}$ \\
\hline
\end{tabular}

Similar letter(s) in a row are non-significant statistically at $\mathrm{P} \leq 0.05$. Figures in parentheses represent the standard errors. * represents the significant statistical difference between the means of each treatment whereas NS indicates the non-significant statistical difference.

These findings are similar to that of Iqbal et al. (2010) who stated that different pollination techniques improved fruit quality parameters in cv. Dhakki. The decrease in fruit moisture content was also observed in cv. Saidy in dusting and pollen grains suspension methods, however, the pollination with these two methods enhanced the fruit chemical constituents such as total soluble solids and sugar contents (Shaaban et al., 2019). El-Mardi et al. (1998) obtained higher nonreducing sugar when cv. Fard pollinated by hand. Ullah et al. (2018) recorded highest total soluble solids in cv. Hillawi when pollinated with dusting method. Samouni et al. (2016) stated that hand pollination and dusting methods behaved alike regarding fruit moisture content, total soluble solids and sugar contents in cv. Saidy.

Table 4 indicated the association between different physicochemical characters of date palm cv. Khalas. There was a significant positive correlation between fruit set percentage and tamar fruit percentage, bunch weight, total soluble solids, total sugar; parthenocarpic fruit percentage and fruit drop percentage; biser fruit percentage and total number of fruit nodes per bunch, seed width, seed ratio; tamar

fruit percentage and bunch weight, total soluble solids; total number of fruit nodes per bunch and seed width; bunch weight and fruit volume, total soluble solids, total sugar; fruit fresh weight and fruit dry weight, fruit length, fruit width, fruit volume, pulp weight, pulp : seed ratio, pulp ratio; fruit dry weight and fruit length, fruit width, fruit volume, pulp weight, pulp : seed ratio, pulp ratio; fruit length and fruit width, fruit volume, pulp weight, total soluble solids; fruit width and pulp weight, pulp : seed ratio, pulp ratio; fruit volume and pulp weight, pulp : seed ratio, pulp ratio, total soluble solids; seed weight and seed ratio, fruit moisture content; pulp weight and pulp : seed ratio, pulp ratio; pulp : seed ratio and pulp ratio; seed ratio and fruit moisture content; total soluble solids and total sugar; total sugar and reducing sugar. These results indicated that highest fruit set significantly enhanced tamar fruit, bunch weight, total soluble solids and total sugar and where there was higher parthenocarpic fruits there was more fruit drop. Similarly, increase in tamar fruit increased bunch weight and total soluble solids. Bunch weight had an analogous relationship with fruit volume, total soluble solids and total sugar. Likewise, pulp: seed ratio increased with the increase in pulp ratio. 


\section{Muhammad Munir et al.}

Table-4: Correlation matrix of different plant characteristics of date palm cv. Khalas.

\begin{tabular}{|c|c|c|c|c|c|c|c|c|c|c|c|c|c|c|c|c|c|c|c|c|c|c|c|}
\hline & FSP & PFP & BFP & FDP & TFP & TFN & BW & FFW & FDW & FL & FW & FV & SWT & SL & SW & PW & PSR & PR & SR & FMC & TSS & TS & RS \\
\hline PFP & $-0.98^{*}$ & & & & & & & & & & & & & & & & & & & & & & \\
\hline BFP & $-0.71^{\mathrm{NS}}$ & $0.81^{\mathrm{NS}}$ & & & & & & & & & & & & & & & & & & & & & \\
\hline FDP & $-0.99^{\circ}$ & $0.98^{\circ}$ & $0.69^{\mathrm{Ns}}$ & & & & & & & & & & & & & & & & & & & & \\
\hline TFP & $0.99 *$ & $-0.99^{*}$ & $-0.75^{\mathrm{NS}}$ & $-0.99^{\circ}$ & & & & & & & & & & & & & & & & & & & \\
\hline TFN & $-0.59^{\mathrm{NS}}$ & $0.70^{\mathrm{Ns}}$ & $0.98^{*}$ & $0.55^{\mathrm{NS}}$ & $-0.64^{\mathrm{NS}}$ & & & & & & & & & & & & & & & & & & \\
\hline BW & $0.97^{\circ}$ & $-0.99^{\circ}$ & $-0.85^{\mathrm{NS}}$ & $-0.97^{\circ}$ & $0.98^{*}$ & $-0.75^{\mathrm{NS}}$ & & & & & & & & & & & & & & & & & \\
\hline FFW & $0.74^{\mathrm{Ns}}$ & $-0.84^{\mathrm{NS}}$ & $-0.99^{\circ}$ & $-0.73^{\mathrm{NS}}$ & $0.78^{\mathrm{NS}}$ & $-0.98^{\circ}$ & $0.87^{\mathrm{Ns}}$ & & & & & & & & & & & & & & & & \\
\hline FDW & $0.73^{\mathrm{NS}}$ & $-0.83^{\mathrm{NS}}$ & $-0.99^{*}$ & $-0.72^{\mathrm{NS}}$ & $0.78^{\mathrm{NS}}$ & $-0.98^{\circ}$ & $0.87^{\mathrm{NS}}$ & $0.99^{\circ}$ & & & & & & & & & & & & & & & \\
\hline FL & $0.82^{\mathrm{NS}}$ & $-0.87^{\mathrm{Ns}}$ & $-0.94^{\mathrm{NS}}$ & $-0.82^{\mathrm{NS}}$ & $0.86^{\mathrm{NS}}$ & $-0.91^{\mathrm{NS}}$ & $0.91^{\mathrm{NS}}$ & $0.95^{\circ}$ & $0.95^{\circ}$ & & & & & & & & & & & & & & \\
\hline FW & $0.71^{\mathrm{NS}}$ & $-0.79^{\mathrm{Ns}}$ & $-0.99^{*}$ & $-0.69^{\mathrm{Ns}}$ & $0.75^{\mathrm{NS}}$ & $-0.98^{\circ}$ & $0.84^{\mathrm{NS}}$ & $0.98^{\circ}$ & $0.99^{\circ}$ & $0.97^{\circ}$ & & & & & & & & & & & & & \\
\hline $\mathrm{FV}$ & $0.86^{\mathrm{Ns}}$ & $-0.92^{\mathrm{NS}}$ & $-0.96^{\circ}$ & $-0.85^{\mathrm{NS}}$ & $0.89^{\mathrm{NS}}$ & $-0.92^{\mathrm{NS}}$ & $0.95^{\circ}$ & $0.97^{\circ}$ & $0.97^{\circ}$ & $0.98^{\circ}$ & $0.97^{\mathrm{xs}}$ & & & & & & & & & & & & \\
\hline SWT & $-0.86^{\mathrm{NS}}$ & $0.94^{\mathrm{NS}}$ & $0.92^{\mathrm{NS}}$ & $0.85^{\mathrm{NS}}$ & $-0.89^{\mathrm{Ns}}$ & $0.84^{\mathrm{NS}}$ & $-0.95^{\mathrm{Ns}}$ & $-0.94^{\mathrm{NS}}$ & $-0.93^{\text {NS }}$ & $-0.87^{\mathrm{NS}}$ & $-0.88^{\mathrm{NS}}$ & $-0.94^{\mathrm{NS}}$ & & & & & & & & & & & \\
\hline $\mathrm{SL}$ & $-0.45^{\mathrm{NS}}$ & $0.53^{\mathrm{NS}}$ & $0.87^{\mathrm{NS}}$ & $0.43^{\mathrm{NS}}$ & $-0.50^{\mathrm{Ns}}$ & $0.94^{\mathrm{NS}}$ & $-0.60^{\mathrm{Ns}}$ & $-0.86^{\mathrm{NS}}$ & $-0.87^{\mathrm{NS}}$ & $-0.87^{\mathrm{Ns}}$ & $-0.92^{\mathrm{NS}}$ & $-0.82^{\mathrm{NS}}$ & $0.63^{\mathrm{NS}}$ & & & & & & & & & & \\
\hline SW & $-0.53^{\mathrm{NS}}$ & $0.67^{\mathrm{NS}}$ & $0.96^{\circ}$ & $0.51^{\mathrm{NS}}$ & $-0.58^{\mathrm{NS}}$ & $0.95^{\circ}$ & $-0.70^{*}$ & $-0.95^{\circ}$ & $-0.95^{*}$ & $-0.80^{\mathrm{NS}}$ & $-0.92^{\mathrm{NS}}$ & $-0.84^{\mathrm{NS}}$ & $0.87^{\mathrm{Ns}}$ & $0.81^{\mathrm{NS}}$ & & & & & & & & & \\
\hline PW & $0.75^{\mathrm{NS}}$ & $-0.85^{\mathrm{NS}}$ & $-0.99^{*}$ & $-0.74^{\mathrm{NS}}$ & $0.79^{\mathrm{NS}}$ & $-0.97^{\circ}$ & $0.88^{\mathrm{NS}}$ & $0.99^{\circ}$ & $0.99^{\circ}$ & $0.95^{\circ}$ & $0.98^{\circ}$ & $0.97^{\circ}$ & $-0.94^{\circ}$ & $-0.85^{\mathrm{NS}}$ & $-0.95^{\circ}$ & & & & & & & & \\
\hline PSR & $0.77^{\mathrm{Ns}}$ & $-0.87^{\mathrm{NS}}$ & $-0.99^{*}$ & $-0.76^{\mathrm{NS}}$ & $0.81^{\mathrm{NS}}$ & $-0.95^{\circ}$ & $0.90^{\mathrm{NS}}$ & $0.99^{\circ}$ & $0.99^{\circ}$ & $\mid 0.94^{\mathrm{NS}}$ & $0.97^{\circ}$ & $0.97^{\circ}$ & $-0.96^{\circ}$ & $-0.81^{\mathrm{NS}}$ & $-0.94^{\circ}$ & $0.99^{\circ}$ & & & & & & & \\
\hline PR & $0.82^{\mathrm{Ns}}$ & $-0.91^{\mathrm{NS}}$ & $-0.97^{*}$ & $-0.81^{\mathrm{NS}}$ & $0.85^{\mathrm{NS}}$ & $-0.92^{\mathrm{NS}}$ & $0.93^{\mathrm{NS}}$ & $0.98^{\circ}$ & $0.98^{\circ}$ & $0.92^{\mathrm{NS}}$ & $0.95^{\circ}$ & $0.97^{\circ}$ & $-0.98^{\circ}$ & $-0.75^{\mathrm{NS}}$ & $-0.92^{\mathrm{NS}}$ & $0.98^{\circ}$ & $0.99^{\circ}$ & & & & & & \\
\hline SR & $-0.82^{\mathrm{NS}}$ & $0.91^{\mathrm{NS}}$ & $0.97^{\circ}$ & $0.81^{\mathrm{Ns}}$ & $-0.85^{\mathrm{NS}}$ & $0.92^{\mathrm{NS}}$ & $-0.93^{\text {NS }}$ & $-0.98^{*}$ & $-0.98^{\mathrm{NS}}$ & $-0.92^{\mathrm{NS}}$ & $-0.95^{*}$ & $-0.97^{*}$ & $0.98^{\circ}$ & $0.75^{\mathrm{NS}}$ & $0.92^{\mathrm{NS}}$ & $-0.98^{\circ}$ & $-0.99^{\circ}$ & $-0.99^{*}$ & & & & & \\
\hline FMC & $-0.84^{\mathrm{NS}}$ & $0.92^{\mathrm{NS}}$ & $0.92^{\mathrm{Ns}}$ & $0.82^{\mathrm{Ns}}$ & $-0.86^{\mathrm{NS}}$ & $0.84^{\mathrm{NS}}$ & $-0.93^{\mathrm{NS}}$ & $-0.94^{\mathrm{NS}}$ & $-0.93^{\mathrm{NS}}$ & $-0.85^{\mathrm{Ns}}$ & $-0.88^{\mathrm{NS}}$ & $-0.92^{\mathrm{NS}}$ & $0.99^{*}$ & $0.63^{\mathrm{NS}}$ & $0.89^{\mathrm{NS}}$ & $-0.94^{\circ}$ & $-0.96^{\circ}$ & $-0.98^{*}$ & $0.98^{\circ}$ & & & & \\
\hline TSS & $0.94^{\circ}$ & $-0.96^{*}$ & $-0.89^{\mathrm{NS}}$ & $-0.94^{\mathrm{NS}}$ & $0.96^{\circ}$ & $-0.82^{\mathrm{NS}}$ & $0.98^{\circ}$ & $0.90^{\mathrm{NS}}$ & $0.90^{\mathrm{NS}}$ & $0.97^{\circ}$ & $0.90^{\mathrm{NS}}$ & $0.97^{\circ}$ & $-0.91^{\mathrm{NS}}$ & $-0.72^{\mathrm{NS}}$ & $\mid-0.73^{\mathrm{NS}}$ & $0.91^{\mathrm{NS}}$ & $0.91^{\mathrm{NS}}$ & $0.92^{\mathrm{NS}}$ & $-0.92^{\mathrm{NS}}$ & $\mid-0.89^{\mathrm{NS}}$ & & & \\
\hline TS & $0.97^{\circ}$ & $-0.94^{\mathrm{Ns}}$ & $-0.73^{\mathrm{NS}}$ & $-0.97^{\circ}$ & $0.97^{\mathrm{NS}}$ & $-0.65^{\mathrm{NS}}$ & $0.95^{\circ}$ & $0.76^{\mathrm{NS}}$ & $0.76^{\mathrm{NS}}$ & $0.90^{\text {NS }}$ & $0.76^{\mathrm{Ns}}$ & $0.89^{\mathrm{NS}}$ & $-0.80^{\mathrm{NS}}$ & $-0.59^{\mathrm{vs}}$ & $-0.52^{\mathrm{NS}}$ & $0.77^{\mathrm{NS}}$ & $0.77^{\mathrm{NS}}$ & $0.80^{\mathrm{NS}}$ & $-0.80^{\mathrm{NS}}$ & $-0.77^{\mathrm{Ns}}$ & $0.97^{*}$ & & \\
\hline RS & $0.89^{\mathrm{NS}}$ & $-0.84^{\mathrm{NS}}$ & $-0.63^{\mathrm{NS}}$ & $-0.90^{\mathrm{NS}}$ & $0.89^{\mathrm{NS}}$ & $-0.56^{\mathrm{NS}}$ & $0.86^{\mathrm{NS}}$ & $0.65^{\mathrm{NS}}$ & $0.66^{\mathrm{NS}}$ & $0.85^{\mathrm{NS}}$ & $0.68^{\mathrm{NS}}$ & $0.81^{\mathrm{NS}}$ & $-0.66^{\mathrm{NS}}$ & $-0.57^{\mathrm{NS}}$ & $-0.38^{\mathrm{NS}}$ & $0.65^{\mathrm{NS}}$ & $0.65^{\mathrm{NS}}$ & $0.67^{\mathrm{Ns}}$ & $-0.67^{\mathrm{Ns}}$ & $\mid-0.62^{\mathrm{NS}}$ & $0.90^{\mathrm{NS}}$ & $0.97^{\circ}$ & \\
\hline NRS & $0.74^{\mathrm{NS}}$ & $-0.83^{\mathrm{NS}}$ & $-0.76^{\mathrm{NS}}$ & $-0.73^{\mathrm{NS}}$ & $0.76^{\mathrm{NS}}$ & $-0.65^{\mathrm{NS}}$ & $0.81^{\mathrm{NS}}$ & $0.78^{\mathrm{Ns}}$ & $0.77^{\mathrm{Ns}}$ & $0.63^{\mathrm{Ns}}$ & $0.68^{\mathrm{Ns}}$ & $0.74^{\mathrm{Ns}}$ & $-0.93^{\mathrm{NS}}$ & $-0.35^{\mathrm{NS}}$ & $-0.78^{\mathrm{NS}}$ & $0.79^{\mathrm{Ns}}$ & $0.82^{\mathrm{NS}}$ & $0.87^{\mathrm{NS}}$ & $-0.87^{\mathrm{Ns}}$ & \begin{tabular}{|l|l} 
& -0.95 \\
\end{tabular} & $0.72^{\mathrm{Ns}}$ & $0.60^{\mathrm{NS}}$ & $0.40^{\mathrm{NS}}$ \\
\hline
\end{tabular}

${ }^{*}$ denotes significant correlation at $\mathrm{P} \leq 0.05$ whereas ${ }^{\mathrm{NS}}$ indicates non-significant correlation at $\mathrm{P} \leq 0.05$. Parameters abbreviated in the Table 4 as: Fruit set percentage (FSP), parthenocarpic fruit percentage (PFP), biser fruit percentage (BFP), fruit drop percentage (FDP), tamar fruit percentage (TFP), total number of fruit nodes per bunch (TFN), bunch weight (BW), fruit fresh weight (FFW), fruit dry weight (FDW), fruit length (FL), fruit width (FW), fruit volume (FV), seed weight (SWT), seed length (SL), seed width (SW), pulp weight (PW), pulp : seed ratio (PSR), pulp ratio (PR), seed ratio (SR), fruit moisture content (FMC), total soluble solids (TSS), total sugar (TS), reducing sugar (RS) and non-reducing sugar (NRS).

On the other hand, there was a significant negative correlation between fruit set percentage and parthenocarpic fruit percentage, fruit drop percentage; parthenocarpic fruit percentage and tamar fruit percentage, bunch weight, total soluble solids; biser fruit percentage and fruit fresh weight, fruit dry weight, fruit width, fruit volume, pulp weight, pulp : seed ratio, pulp ratio; fruit drop percentage and tamar fruit percentage, bunch weight, total sugar; total number of fruit nodes per bunch, fruit fresh weight, fruit dry weight, fruit width, pulp weight, pulp : seed ratio; bunch weight and seed width; fruit fresh weight and seed width, seed ratio; fruit dry weight and seed width; fruit width and seed ratio; fruit volume and seed ratio; seed weight and pulp weight, pulp : seed ratio, pulp ratio; seed width and pulp weight, pulp : seed ratio; pulp weight and seed ratio, fruit moisture content; pulp : seed ratio and seed ratio, fruit moisture content; pulp ratio and seed ratio, fruit moisture content. It is revealed that increase in fruit set significantly decreased parthenocarpic fruits and fruit drop whereas decrease in parthenocarpic fruits increased tamar fruits, bunch weight and total soluble solids. Similarly, the decrease in fruit drop significantly increased tamar fruits, bunch weight and total sugar. The increase in bunch weight was corresponding to the decrease in seed width while the increase in fruit fresh weight was related to the decrease in seed width and seed ratio. An antagonistic relationship was observed between pulp : seed ratio and seed ratio and fruit moisture content. 


\section{Conclusion}

In date palm cv. Khalas different pollination methods (dusting, strands placement, pollen suspension, and natural pollination) significantly affected the fruit set percentage, bunch weight, and fruit quality parameters. Pollen grains dusting method was found most effective technique followed by pollen grains suspension method. Although the strands placement method was best as compared to natural pollination method, however, the former technique did not compete with the dusting and pollens suspension ones. Pollen dusting and pollen suspension methods are more beneficial due to the shortage of skilled field labor and higher cost, as these techniques are simple, easier and cost effective than strands placement manual pollination technique. However, further studies can be conducted to investigate the efficiency of dusting tools, pollination frequency of dusting material, and the ratio of inert material mixed with pollens for dusting purpose.

\section{Acknowledgement}

This project (DPRC-11-2016) was granted by the Date Palm Research Center of Excellence, King Faisal University, Kingdom of Saudi Arabia for which we are grateful.

\section{Disclaimer: None.}

\section{Conflict of Interest: None.}

Source of Funding: This study was funded by Date Palm Research Center of Excellence, King Faisal University, Kingdom of Saudi Arabia.

\section{References}

Abbas MF and Ibrahim MA, 1996. The role of ethylene in the regulation of fruit ripening in the Hillawi date palm (Phoenix dactylifera L). J. Sci. Food Agric. 72: 306-308.

Abbas MF and Ibrahim MA, 1998. Effect of pollen parent on the physiology of ripening of date palm fruit (Phoenix dactylifera L). Basrah J. Agric. Sci. 11: 31-37.

Abdel-Sattar M and Mohamed YI, 2017. Pollen viability of date palm from different sources in relation to its chemical composition. Alex. J. Agric. Sci. 62: 149-155.
Abd-Rabou AFN and Radwan ES, 2017. The current status of the date palm (Phoenix dactylifera) and its uses in the Gaza Strip, Palestine. Biodiversitas. 18: 1047-1061.

Abu-Zahra TA and Shatnawi MA, 2019. New pollination technique in date palm (Phoenix dactylifera L.) cv. "Barhee" and "Medjol" under Jordan valley conditions. American-Eur. J. Agric. Environ. Sci. 19: 37-42.

Ahmed EFS, Saied HHM and El-Sharabasy SFA, 2016. Pistil receptivity of Saidy date palms grown under new valley conditions when pollinated with pollen suspension. J. Plant Prod. 7: 1179-1182.

Al-Abdoulhadi IA, Dinar HA, Ebert G and Buttner C, 2011. Effect of salinity on leaf growth, leaf injury and biomass production in date palm cultivators. Ind. J. Sci. Technol. 4: 1542-1546.

Al-Wusaibai NA, Abdallah AB, Al-Husainai MS, AlSalman H and Elballaj M, 2012. A comparative study between mechanical and manual pollination in two premier Saudi Arabian date palm cultivars. Ind. J. Sci. Technol. 5: 2487-2490.

AOAC, 2016. Official Methods of Analysis of AOAC International. G.W. Latimer Jr (ed.), $20^{\text {th }}$ Edition. Maryland, USA.

Attalla AM, Warring MO and Sharaan FA, 1998. Suitable time of two Saudi date palm cultivars. Alex. J. Agric. Res. 43: 203-208.

Awad MA, 2010. Pollination of date palm (Phoenix dactylifera L.) cv. Khenazy by pollen grain-water suspension spray. J. Food Agric. Environ. 88: 313-317.

Bekheet SA and Hanafy MS, 2011. Towards sex determination of date palm, pp. 551-566. In S.M. Jain, J.M. Al-Khayri and D.V. Johnson (eds.), Date Palm Biotechnology. Springer, Dordrecht, Netherlands.

Bower J, Holford P, Latché A and Pech JC, 2002. Culture conditions and detachment of the fruit influence the effect of ethylene on the climacteric respiration of melon. Postharvest Biol. Technol. 26: $135-146$.

Cohen Y, Slavkovic F, Birger D, Greenberg A, Sadowsky A, Ish-Shalom M, Benita M, Ticuchinski T, Avnat Y and Kamenetsky R, 2016. Fertilization and fruit setting in date palm: biological and technological challenges. Acta Hort. 1130: 351-358.

El-Dengawy EFA, 2017. Improvement of the pollination technique in date palm. J. Plant Prod. 8: 307-314. 
El-Mardi MO, Al Said FAJ Sakit CB Al Kharusi LM Al Rahbi IN and Al Mahrazi K, 2007. Effect of pollination method, fertilizer and mulch treatments on the physical and chemical characteristics of date palm (Phoenix dactylifera) fruit. I: Physical characteristics. Acta Hort. 736: 317-328.

El-Mardi MO, Consolacion EC, Abdelbasit KM, AIMarozouqi M and AI-Mantheri OS, 1998. Evaluation of the pollination method and pollen concentration on chemical characteristics of date fruit from Fard cultivar, pp. 49-61. In Proceedings, First International Conference on Date Palms, 8-10 March 1998, Al-Ain, UAE.

FAOSTAT, 2017. Food and Agriculture Organization of the United Nations. Retrieved from http://faostat.fao.org/site

Gupta A, Godara RK Sharma VK and Panda AK, 2017. Artificial pollination: A tool for improving fruiting traits in date palm (Phoenix dactylifera L.). Chem. Sci. Rev. Lett. 6: 1312-1320.

Haffar I, Al-Juburi H and Ahmed MH, 1997. Effect of pollination frequency and pollen concentration on yield and fruit characteristics of mechanically pollinated date palm trees (Phoenix dactylifera var. Khalas). J. Agric. Engg. Res. 68: 11-14.

Hajian S, 2005. Fundamentals of pollination in date palm plantations in Iran, pp. 252-259. In Proceedings, First International Conference on Mango and Date Palm: Culture and Export. 20-23 June 2005, University of Agriculture, Faisalabad, Pakistan.

Higashiyama $\mathrm{T}$ and Takeuchi H, 2015. The mechanism and key molecules involved in pollen tube guidance. Annu. Rev. Plant Biol. 66: 393-413.

Iqbal M, Khan MQ, Munir M, Rehman SU, Rehman HU and Niamatullah M, 2010. Effect of different pollination techniques on fruit set, pomological characters and yield of Dhakki date palm (Phoenix dactylifera L) in Dera Ismail Khan, KP. Sarhad J. Agric. 26: 515-518.

Iqbal M, Munir M, Subhan M and Khan MQ, 2005. Effect of different pollination methods fruit set, pomological characters and yield of date palm (Phoenix dactylifera L.) cv. Dhakki under the agro-climatic conditions of Dera Ismail Khan, pp. 219-224. In Proceedings, First International Conference on Mango and Date Palm: Culture and Export. 20-23 June 2005, University of Agriculture, Faisalabad, Pakistan.
Jacobsen SE and Olszewski NE, 1993. Mutations at the SPINDLY locus of Arabidopsis alter gibberellin signal transduction. Plant Cell. 5: 887896.

Khan H and Khan AG, 1993. Improvement and development of date palm production in D.I.Khan, Volume I, pp. 349-359. In Proceedings, Third Symposium on Date palm in Saudi Arabia, King Faisal University, Al-Hassa, Saudi Arabia.

Mostaan A, Marashi SS and Ahmadizadeh S, 2010. Development of a new date palm pollinator. Acta Hort. 882: 315-320.

Munir M, 2019. Influence of liquid pollination technique on fruit yield and physicochemical characteristics of date palm cultivars Khadrawy and Zahidi. J. Appl. Hort. 21(3): 12-17.

Pandolfini T, Molesini B and Spena A, 2018. Parthenocarpy in crop plants. In L. Ostergaard (ed.). Fruit Development and Seed Dispersal, vol. 38. Annual Plant Review Book Series, WileyBlackwell, New Jersey, USA.

Ream CL and Furr JR, 1969. The period of receptivity of pistillate flowers and other factors effecting fruit set of date fruit. Date Growers Institute Rep. 46: 28-29.

Saltveit ME, 1993. Internal carbon dioxide and ethylene levels in ripening tomato fruit attached to or detached from the plant. Physiol. Plant. 89: 204-210.

Samouni MTM, El-Salhy AM, Badawy IFM and Ahmed EF, 2016. Effect of pollination and thinning methods on yield and fruit quality of Saidy date palms. Assiut J. Agric. Sci. 47: 92-103.

Shaaban MM, Ahmed EFS and El-Akkad MM, 2019. Studies on the improvement of date palm productivity using different methods of pollination and fruit thinning levels. J. Plant Prod. 10: 373-377.

Shafique M, Ahmad SK, Aman UM, Shahid M, Ishtiaq AR, Basharat AS, Amin A and Iftikhar A, 2011. Influence of pollen source and pollination frequency of fruit drop, yield and quality of date palm (Phoenix dactylifera L.) cv. Dhakki. Pak. J. Bot. 43: 831-839.

Smith AV and Koltunow AM, 1999. Genetic analysis of growth-regulator-induced parthenocarpy in Arabidopsis. Plant Physiol. 121: 437-451.

Takeuchi H and Higashiyama TA, 2012. Speciesspecific cluster of defensin-like genes encodes diffusible pollen tube attractants in Arabidopsis. PLoS Biol. 10: e1001449. 
Ullah M, Ahmad F, Iqbal J, Imtiaz M and Raza MK, 2018. Effects of different pollination methods on fruit quality and yield of date palm candidate line Hillawi. J. Environ. Agric. Sci. 17: 55-62.

Zaid A and de Wet PF, 2002. Pollination and Bunch Management. In A. Zaid and E.J. Arias-Jiménez (eds.), Date Palm Cultivation. FAO Plant Production and Protection Paper 156 Rev. 1. Food and Agricultural Organization of the United Nations, Rome, Italy. http://www.fao.org/3/Y4360E/y4360e0c.htm

\section{Contribution of Authors}

Munir M: Conceived the idea, designed the study, supervised research project and wrote the full article Al-Hajhoj MR: Co-supervised research study and performed data analysis

Ghazzawy HS: Assisted in field data collection and layout of experiment

Sallam AKM: Contributed in the framing and executing the research idea, assisted in design layout and proofreading

Al-Bahigan AM: Assisted in data collection and laboratory work

Al-Muiweed MA: Assisted in data collection and laboratory work. 